\title{
Erratum to: NTRK2 expression levels are reduced in laser captured pyramidal neurons from the anterior cingulate cortex in males with autism spectrum disorder
}

\author{
Michelle J Chandley ${ }^{1}$, Jessica D Crawford ${ }^{2}$, Attila Szebeni ${ }^{2}$, Katalin Szebeni ${ }^{2}$ and Gregory A Ordway ${ }^{2 *}$
}

\section{Erratum}

Upon publication of [1], it was noticed by the author that the caption for figure six was incorrect. The correction caption for figure six is as follows:

Figure six. Levels of expression of SLC1A1, GRIP1, and NTRK2 in punch-dissected BA24 gray matter. Gene expression was measured in typically developing control donors (open symbols) and ASD donors (closed symbols) using RNA isolated from homogenates of puncheddissected gray matter rather than specific laser captured cells as shown in Figs. 1-5. Gene expression levels were determined by real time PCR and are normalized to the geometric mean of stable references genes (GAPDH, TBP, and Ribo18S1). No statistically significant differences were observed.

\section{Author details}

'Department of Health Sciences, College of Public Health, East Tennessee

State University, P.O. Box 70673, Johnson City, TN 37614, USA. ${ }^{2}$ Department of Biomedical Sciences, James H. Quillen College of Medicine, East

Tennessee State University, P.O. Box 70582, Johnson City, TN 37614, USA.

Received: 9 June 2015 Accepted: 9 June 2015

Published online: 20 June 2015

\section{Reference}

1. Chandley MJ, Crawford JD, Szebeni A, Szebeni K, Ordway GA. NTRK2 expression levels are reduced in laser captured pyramidal neurons from the anterior cingulate cortex in males with autism spectrum disorder. Mol Autism. 2015;6:28.

\footnotetext{
* Correspondence: ordway@etsu.edu

${ }^{2}$ Department of Biomedical Sciences, James H. Quillen College of Medicine, East Tennessee State University, P.O. Box 70582, Johnson City, TN 37614, USA

Full list of author information is available at the end of the article
}

Submit your next manuscript to BioMed Central and take full advantage of:

- Convenient online submission

- Thorough peer review

- No space constraints or color figure charges

- Immediate publication on acceptance

- Inclusion in PubMed, CAS, Scopus and Google Scholar

- Research which is freely available for redistribution 